JAMP: Jurnal Adminitrasi dan Manajemen Pendidikan

Volume 1 Nomor 3 September 2018, Hal : 293-301

Tersedia Online di http://journal2.um.ac.id/index.php/jamp/

ISSN 2615-8574 (online)

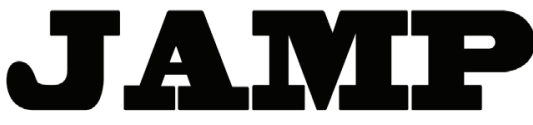

JURNAL ADMINISTRASI DAN MANAJEMEN PENDIDIKAN

\title{
PELIBATAN KOMITE SEKOLAH DALAM PENINGKATAN MUTU PENDIDIKAN
}

\author{
Dyah Nur Septiana \\ Ibrahim Bafadal \\ Desi Eri Kusumaningrum \\ dyahnurss@gmail.com
}

Universitas Negeri Malang, Jl. Semarang No. 5 Malang 65145

\begin{abstract}
This research aims to describe; (1) the strength of the school committee; (2) forms of school committee involvement; (3) the headmaster that strategy involves school committee; (4) obstacles of the school committee; (5) committee's problem solving alterative in SDN Blimbing 4 Malang. This research uses qualitative approach with case study research type. The data collection techniques are that used observation, interview and documentation. Based on the process of collecting and analyzing, the result of the obtained data are: (1) the strength of the committee derived comes from the readiness, the alertness to solve the problem, the clear division of labor, and the good coordination; (2) forms of committee involvement are: holding meetings, raising funds, controlling the finances, directing and involving parents in the program, reporting the results of activities to parents; (3) the strategy of the headmaster involves the committees are coordinating, approaching, and becoming a role model; (4) the obstacle of school committee constraints such as committee managers are rarely complete during meetings, the guardian objected to donate voluntary; (5) the problem solving alternatives are the absent committee board is replaced by another committee, and take personal approach.
\end{abstract}

Keyword : involvement, school committee, improving the quality of education

\begin{abstract}
Abstrak: Tujuan penelitian ini mendeskripsikan; (1) kekuatan komite sekolah; (2) bentukbentuk pelibatan komite sekolah; (3) strategi kepala sekolah melibatkan komite sekolah; (4) kendala-kendala komite sekolah; (5) alternatif pemecahan masalah komite di SDN Blimbing 4 Malang. Penelitian ini menggunakan pendekatan kualitatif dengan jenis penelitian studi kasus. Teknik pengumpulan data yang digunakan ialah observasi, wawancara dan dokumentasi. Berdasarkan proses pengumpulan dan analisis data didapatkan hasil, yaitu: (1) kekuatan komite berasal dari keaktifan, kesigapan menindaklanjuti masalah, pembagian kerja yang jelas, dan koordinasi yang baik; (2) bentuk-bentuk pelibatan komite yaitu: mengadakan pertemuan, menggalang dana, mengontrol keuangan, mengarahkan dan melibatkan orang tua dalam program, melaporkan hasil kegiatan kepada orang tua; (3) strategi kepala sekola melibatkan komite yaitu berkoordinasi, melakukan pendekatan-pendekatan, dan kepala sekolah menjadi tauladan; (4) kendala-kendala komite sekolah diantaranya pengurus komite jarang lengkap saat pertemuan, wali murid keberatan saat sumbangan sukarela; (5) alternatif pemecahan masalah yakni pengurus yang tidak hadir digantikan dengan pengurus lainnya, melakukan pendekatan secara personal.
\end{abstract}

Kata Kunci: pelibatan, komite sekolah, peningkatan mutu pendidikan

Pendidikan merupakan sarana pencetak generasi bangsa yang diharapkan dapat menjadi bagian penting dalam proses pembangunan nasional. Pendidikan mampu menghasilkan insan-insan yang berkualitas, berperilaku dan mampu berperan aktif memajukan bangsa. Kesadaran dan minat terhadap pentingnya pendidikan bagi setiap warga negara perlu ditumbuhkembangkan agar tujuan diatas dapat tercapai sesuai 
dengan Undang-Undang Sistem Pendidikan Nasional Nomor 20 Tahun 2003 tentang pendidikan yang berbunyi: pendidikan adalah usaha sadar dan terencana untuk mewujudkan suasana belajar dan proses pembelajaran agar peserta didik secara aktif mengembangkan potensi dirinya untuk memiliki kekuatan spiritual, keagamaan, pengendalian diri, kepribadian, kecerdasan, akhlak mulia, serta keterampilan yang diperlukan dirinya, masyarakat, bangsa dan negara.

Penyelenggaraan pendidikan harus berjalan sesuai dengan tujuan pendidikan, yaitu mencerdaskan kehidupan bangsa. Sebab, salah satu indikasi kemajuan bangsa terletak pada pendidikan yang bermutu, sehingga mampu menghasilkan output yang memberikan perubahan-perubahan bagi bangsanya. Kualitas pendidikan dicapai dengan melakukan penataan dan pengelolaan yang baik pada semua komponen. di awali dengan sistem pendidikan mulai jalur pendidikan formal, pendidikan non formal, maupun pendidikan informal. Sekolah merupakan tempat belajar untuk memperoleh pendidikan dan pengetahuan, sekolah sebagai wujud lembaga pendidikan dituntut melakukan perubahan dan perkembangan secara berkelanjutan untuk memenuhi kebutuhan masyarakat terhadap pendidikan yang lebih baik. Bentuk perubahan yang dapat dilakukan adalah dengan menerapkan kebijakan pemerintah yaitu Manajemen Berbasis Sekolah (MBS). Manajemen Berbasis Sekolah (MBS) menurut Fattah (2013:42): sebagai terjemahan dari School Based Management (SBM), adalah suatu pendekatan praktis yang bertujuan untuk mendesain ulang pengelolaan sekolah dengan memberikan kekuasaan kepada kepala sekolah serta meningkatkan partisipasi masyarakat dalam upaya perbaikan kinerja sekolah yang mencakup guru, siswa, kepala sekolah, orang tua siswa, dan masyarakat.

Maka dari itu, salah satu upaya yang dapat dilakukan kepala sekolah adalah dengan membangun hubungan yang harmonis dengan komite sekolah. Hubungan yang terjalin baik akan memudahkan kepala sekolah dalam menjalankan program-program sekolah yang mana bertujuan meningkatkan mutu pendidikan utamanya mutu sekolah.

Keberadaan komite sekolah dalam satuan pendidikan merupakan wadah partisipasi masyarakat terhadap layanan pendidikan di sekolah dengan kata lain komite menjembatani hubungan antara sekolah dan masyarakat. Penting untuk komite sekolah menjalankan tugas dan fungsinya agar mutu pendidikan sesuai dengan visi, misi, dan tujuan sekolah. Disamping itu, kepala sekolah berperan sebagai promotor penggerak lembaga pendidikan juga berwenang untuk mengaktifkan komite sekolah dengan cara mengikutsertakannya pada setiap rencana pengembangan program sekolah, pelaksanaan, hingga evaluasi. Salah satu sekolah yang melibatkan komite dalam upaya peningkatan mutu pendidikan adalah SDN Blimbing 4 Malang yang berlokasi di Jalan Laksda Adi Sucipto No. 202 Kecamatan Blimbing, Kota Malang. Sekolah ini telah berhasil melibatkan komite sekolah dengan baik yang bisa dilihat dari segi sarana dan prasarana.

\section{METODE}

Pendekatan yang digunakan dalam penelitian ini adalah kualitatif yang dilakukan bertujuan untuk mendeskripsikan aspek yang menjadi fokus penelitian yang terkait dengan pelibatan komite sekolah dalam peningkatan mutu pendidikan di SDN Blimbing 4 Malang sedangkan jenis penelitian yang digunakan adalah studi kasus tunggal karena penelitian dilakukan pada satu lingkungan saja yaitu di SDN Blimbing 4 Malang yang bertujuan untuk mengetahui dan menemukan fakta atau peristiwa yang dianggap unik yang tidak terjadi pada sekolah lain baik sekolah negeri, sekolah swasta maupun madrasah. Lokasi penelitian yaitu di Sekolah Dasar Negeri (SDN) Blimbing 4 Malang didirikan pada tahun 1974 dengan luas tanah 1.592 m2, yang terletak di Jalan Laksda Adi Sucipto Nomor 202. Telp. (0341) 477713 Kode Pos 65125 Kecamatan Blimbing Kota Malang. Selain itu, SDN Blimbing 4 Malang memiliki jenjang akreditasi SD yaitu A (Amat Baik). Jalan Laksda Adi Sucipto No. 202.

Sumber data dalam penelitian ini yaitu wakil ketua komite, bendahara komite, kepala sekolah, guruguru, dan orang tua atau wali murid SDN Blimbing 4 Malang. Data tambahan yang digunakan adalah dokumen yang dianalisis oleh peneliti, diantaranya: profil sekolah, surat keputusan (SK), Rencana Kerja Tahunan (RKT), serta foto-foto kegiatan yang berkaitan dengan fokus penelitian.

Prosedur pengumpulan data yang digunakan peneliti, yaitu: (1) wawancara mendalam; (2) pengamatan atau observasi; dan (3) Teknik dokumentasi, teknik ini digunakan untuk memperoleh data 
yang sifatnya tertulis maupun tercetak. Proses analisis data yaitu melalui pengumpulan data, reduksi data, penyajian data, dan penarikan kesimpulan. Penelitian ini dilakukan pengecekan keabsahan data dengan mengecek/menguji empat kriteria, yaitu (1) uji kepercayaan atau kredibilitas; (2) keteralihan; (3) ketergantungan; dan (4) kepastian.

\section{HASIL}

Kekuatan komite sekolah di SDN Blimbing 4 Malang terkait upaya penigkatan mutu pendidikan ialah: (1) keaktifan komite dalam program atau kegiatan sekolah. Komite sekolah membantu sekolah dalam hampir semua program sekolah untuk mewujudkan sekolah bermutu; (2) kesigapan komite sekolah dalam menindaklanjuti permasalahan; (3) koordinasi yang baik antara warga sekolah, komite sekolah, dan orang tua atau wali murid; (4) pembagian kerja yang jelas antara ketua komite, wakil ketua komite, sekretaris, dan bendahara.

Bentuk-bentuk pelibatan komite sekolah diantaranya: (1) mengadakan pertemuan untuk berkoodinasi dan menyatukan persepsi bersama kepala sekolah, pengurus komite, pengurus paguyuban, para guru, dan wali murid untuk membahas rencana program atau kegiatan sekolah; (2) komite menggalang dana untuk dapat melaksanakan program sekolah kepada wali murid. Penggalangan dana diperoleh dari wali murid kelas I - VI yang biasa disebut dengan sumbangan sukarela dalam arti lain tidak ada paksaan dalam pelaksanaannya; (3) mengontrol keuangan sekolah yang terkait dengan program atau kegiatan sekolah. Dana yang diperoleh dari sumbangan sukarela wali murid, komite bertugas mengontrol dana tersebut dipergunakan untuk keperluan apa saja; (4) komite melibatkan dan mengarahkan wali murid dalam pelaksaaan program sekolah. wali murid membantu sekolah dalam program misalnya pengadaan kanopi, pembuatan biopori dan sumur resapan hingga kegiatan adiwiyata melibatkan wali murid. Bentuk bantuannya mulai dari materi, tenaga, dan peralatan atau perlengkapan; (5) komite melaporkan hasil kegiatan kepada wali murid saat pertemuan wali murid biasa dilaksanakan ketika penerimaan raport. Laporan tersebut dilakukan komite sebagai bentuk transparansi sekaligus pembuktian bahwa sumbangan sukarela oleh wali murid benar-benar direalisasikan.

Strategi kepala sekolah melibatkan komite sekolah dalam upaya peningkatan mutu pendidikan diantaranya: (1) kepala sekolah berkoordinasi dengan komite sekolah. Hal ini merupakan strategi kepala sekolah yang efektif sehingga komite selalu dilibatkan dalam program atau kegiatan sebagai upaya meningkatkan mutu sekolah maka dari itu dianggap sangat penting; (2) kepala sekolah melakukan pendekatan-pendekatan. Cara ini dilakukan kepala sekolah apabila permasalahan belum dapat terselesaikan didalam forum atau pertemuan sehingga pendekatan secara personal dilakukan; (3) kepala sekolah memposisikan dirinya sebagai contoh atau sosok teladan. Untuk melakukan perubahan tersebut, kepala sekolah memberikan contoh kepada warga sekolah dan masyarakat (komite dan wali murid), hal ini bertujuan untuk membangun kesadaran.

Kendala-kendala dalam melibatkan komite sekolah yaitu: (1) pada saat ada pertemuan tidak semua pengurus komite dapat hadir dikarenakan sibuk dengan pekerjaan masing-masing; (2) wali murid yang tidak setuju dengan program atau kegiatan sekolah. Wali murid yang tidak setuju mayoritas menolak untuk menyumbang dana atau bahkan tidak ikut berpartisipasi seperti kerja bakti.

Alternatif pemecahan masalahnya ialah dengan cara berikut: (1) komite yang berhalangan hadir dapat digantikan oleh pengurus komite lainnya namun tetap berkoordinasi dengan pengurus yang tidak hadir; (2) solusi lainnya untuk mengatasi wali murid yang tidak setuju adalah dengan melakukan pendekatan secara personal terhadap pihak-pihak yang bertentangan tersebut.

\section{PEMBAHASAN}

Sekolah sebagai lembaga pendidikan yang berfungsi sebagai tempat penyelenggaraan pendidikan juga sekaligus sebagai lembaga layanan masyarakat yang bergerak di bidang pendidikan. Oleh karena itu, untuk mencapai tujuan pendidikan diperlukan kerjasama dari berbagai pihak seperti kepala sekolah, para guru dan tenaga pendidikan, serta masyarakat. Masyarakat disini artinya orang tua/wali murid, 
komite sekolah, stakeholder dan masyarakat sekitar sekolah. Wujud kerjasama yang dilakukan SDN Blimbing 4 Malang yakni bekerjasama dengan komite sekolah. Komite sekolah sebagaimana yang tercantum dalam Permendikbud Nomor 75 Tahun 2016 tentang Komite Sekolah bahwa "komite sekolah adalah lembaga mandiri yang beranggotakan orangtua/wali peserta didik, komunitas sekolah, serta tokoh masyarakat yang peduli pendidikan". Hal ini sesuai dengan hasil temuan penelitian bahwa komite SDN Blimbing 4 Malang telah dibentuk kepengurusan yang terdiri dari ketua komite, wakil ketua komite, Sekretaris komite, Bendahara komite, dan Paguyuban wali murid dari masing-masing kelas yang berasal dari kalangan tokoh masyarakat dan orangtua/wali murid. Pembagian tugas pengurus komite tersebut ialah: 1) Ketua komite sekolah bertugas sebagai orang yang menangani permasalahan yang terkait dengan orang tua yang frontal menolak rencana program sekolah, 2) Wakil ketua komite bertugas dalam melakukan pendekatan dengan masyarakat atau hubungan masyarakat, 3) Sekretaris bertugas sebagai memberikan pertimbangan ketika akan melaksanakan suatu progaram terhadap peraturan-peraturan yang berlaku, 4) Bendahara bertugas mengelola keuangan yang diperoleh dari penggalangan dana. Selain itu, bendahara disini memiliki kemampuan dalam teknik pembangunan, 5) Paguyuban wali murid masingmasing kelas yang bertugas membantu pengurus komite sebagai jembatan menyampaikan program sekolah. Paguyuban kelas terdiri dari ketua, sekretaris, dan bendahara.

Pembagian tugas atau peran masing-masing pengurus komite memudahkan dalam melakukan program sekolah. Maka, keaktifan komite untuk berperan serta menjadi salah satu kunci kekuatan komite itu sendiri. Sebagaimana hasil temuan di SDN Blimbing 4 Malang mengenai keaktifan komite sekolah yang dapat diketahui melalui kesigapan dalam menindaklanjuti permasalahan seperti misalnya pengadaan kanopi, pembuatan sumur resapan dan biopori untuk mengatasi banjir di depan musholah. Sehingga untuk melaksanakan program itu diperlukan koordinasi dari beberapa komponen seperti: 1) warga sekolah seperti kepala sekolah, guru-guru dan tenaga kependidikan, 2) pengurus komite sekolah, 3) wali murid/orang tua. Hal itu berbanding lurus dengan penelitian Firdiana (2012:69) mengenai kekuatan komite sekolah dalam program sekolah yaitu: "(1) kesigapan komite sekolah dalam menindaklanjuti suatu informasi yang didapat, (2) rasa kekeluargaan yang tinggi antara warga sekolah dengan masyarakat sekitar, (3) dan koordinasi yang baik antara sekolah dengan komite sekolah”. Kesigapan komite dalam mengatasi permasalahan tercantum dalam Permendikbud Nomor 75 tentang Komite Sekolah pada pasal 2, bahwa Komite Sekolah bertugas "menindaklanjuti keluhan, saran, kritik, dan aspirasi dari peserta didik, orangtua/wali, dan masyarakat serta hasil pengamatan Komite Sekolah atas kinerja Sekolah".

Mewujudkan tujuan pendidikan tidak hanya menjadi tanggungjawab sekolah namun, masyarakat dapat ambil andil untuk membuat perubahan bagi keberlangsungan pendidikan yakni di sekolah. Masyarakat dalam hal ini adalah komite sekolah sebagai partner atau mitra kerja sekolah untuk mengembangkan sekolah demi mencapai tujuan pendidikan. Oleh karena itu, pelibatan komite dalam program atau kegiatan sekolah memiliki peran untuk menyukseskannya. Terkait pelibatan komite, hal ini sebagaimana sesuai dengan konsep yang dikemukakan Pidarta dalam (Dwiningrum, 2011:50): partisipasi adalah pelibatan seseorang atau beberapa orang dalam suatu kegiatan. Keterlibatan dapat berupa keterlibatan mental dan emosi serta fisik dalam menggunakan segala kemampuan yang dimilikinya (berinisiatif) dalam segala kegiatan yang dilaksanakan serta mendukung pencapaian tujuan dan tanggung jawab atas segala keterlibatan.

Pelibatan komite sekolah dapat diketahui dari bentuk-bentuk pelibatan dan kontribusinya untuk sekolah terutama dalam program sekolah sehingga keberadaan komite di dalam satuan pendidikan perlu untuk dibentuk. Pembentukan komite di sekolah memiliki tujuan seperti yang disebutkan Mukhtar, dkk (dalam Kompri, 2014:303) sebagai berikut: “(1) membantu kelancaran penyelenggaraan pendidikan di sekolah, (2) memelihara, meningkatkan, dan mengembangkan sekolah, (3) memantau, mengawasi dan mengevaluasi penyelenggaraan pendidikan di sekolah". Oleh karena itu, komite perlu memahami batas-batas peran dan tugasnya sebagai lembaga mandiri yang bersifat sosial. Temuan penelitian di SDN Blimbing 4 Malang, peran komite sekolah yang pertama, ialah mengadakan pertemuan untuk berkoodinasi dan menyatukan persepsi bersama kepala sekolah, pengurus komite, pengurus paguyuban, para guru, dan wali murid untuk membahas rencana program atau kegiatan sekolah. Hal ini sesuai dengan pendapat Mulyasa (dalam Kompri, 2014:303-304) bahwa dalam pelaksanaannya dapat dilakukan 
dengan "(1) melakukan koordinasi secara intensif dengan pihak sekolah dan, (2) menyelenggarakan rapat penyelenggaraan pendidikan di sekolah". Pendapat yang sama dijelaskan Satori (dalam Sagala, 2011:241), yaitu: mengadakan pertemuan terjadwal untuk menampung dan membahas berbagai kebutuhan, masalah, aspirasi serta ide-ide yang disampaikan oleh anggota Komite Sekolah. hal-hal tersebut merupakan refleksi kepedulian para stakeholder sekolah terhadap berbagai aspek kehidupan sekolah yang ditujukan pada upaya-upaya bagi perbaikan, kemajuan dan pengembangan sekolah.

Bentuk keterlibatan komite SDN Blimbing 4 Malang yang kedua, yaitu komite menggalang dana untuk pelaksanaan program sekolah. Penggalangan dana diperoleh dari wali murid kelas I - VI, penggalangan dana tersebut bersifat sukarela atau biasa disebut sumbangan sukarela sehingga tidak ada paksaan dalam pelaksanaannya. Meski dapat dikatakan dalam pelaksanaannya masih terdapat pro dan kontra, namun yang perlu diketahui adalah kegiatan menggalang dana telah diatur dalam Permendikbud Nomor 75 tentang Komite Sekolah pada pasal 3, disana komite Sekolah bertugas "menggalang dana dan sumber daya pendidikan lainnya dari masyarakat baik perorangan/organisasi/dunia usaha/dunia industri maupun pemangku kepentingan lainnya melalui upaya kreatif dan inovatif'. Selain itu pada pasal 10 ayat 1 dan 2 yaitu: 1 . Komite sekolah melakukan penggalangan dana dan sumber daya pendidikan lainnya untuk melaksanakan fungsinya dalam memberikan dukungan tenaga, sarana dan prasarana, serta pengawasan pendidikan. 2. Penggalangan dana dan sumber daya pendidikan lainnya sebagaimana dimaksud pada ayat (1) berbentuk bantuan dan/atau sumbangan, bukan pungutan.

Selain itu, komite memiliki peran yang lebih dominan dibandingkan sekolah dalam penggalangan dana sehingga keberadaan komite sangat membantu sekolah untuk mewujudkan program/kegiatan guna meningkatkan mutu sekolah. hal ini mengindikasikan bahwa komite menjalankan tugasnya sesuai peran dan fungsinya dengan baik tanpa melewati batas kewenangannya.

Peran atau bentuk keterlibatan komite yang ketiga, ialah mengontrol keuangan sekolah yang terkait dengan program atau kegiatan sekolah. Dana yang diperoleh dari sumbangan sukarela wali murid, komite bertugas mengontrol dana tersebut dipergunakan untuk keperluan apa saja. Menurut Mulyasa (2012:128), komite sekolah berperan sebagai "pengontrol (controlling agency) dalam rangka transparansi dan akuntabilitas penyelenggaraan dan keluaran mutu pendidikan di sekolah". Pengawasan atau pengontrolan oleh komite merupakan salah satu cara komite memperoleh kepercayaan orang tua/wali murid dalam penyelenggaraan pendidikan, lebih khususnya ketika menggunakan dana hasil sumbangan sukarela wali murid.

Bentuk keterlibatan komite yang keempat, Komite melibatkan dan mengarahkan wali murid dalam pelaksaaan program sekolah. Wali murid membantu sekolah dalam program misalnya pengadaan kanopi, pembuatan biopori dan sumur resapan hingga kegiatan adiwiyata melibatkan wali murid. Bentuk bantuannya mulai dari materi, tenaga, dan peralatan atau perlengkapan. Hal ini sesuai pendapat Mulyasa (2013:189-190), bahwa peran komite sekolah adalah "mendorong orangtua dan masyarakat untuk secara aktif berpartisipasi dalam pendidikan guna mendukung peningkatan kualitas, relevansi, dan pemerataan pendidikan". Bantuan orang tua tidak hanya materi melainkan dapat berupa tenaga dan ide-ide. Sehingga dengan komite sekolah melibatkan wali murid dalam program/kegiatan sekolah tersebut dapat membangun kesadaran bahwa masyarakat juga memiliki hak untuk mengembangkan sekolah.

Bentuk keterlibatan komite yang kelima, berdasarkan temuan penelitian ialah komite melaporkan hasil kegiatan kepada wali murid saat pertemuan wali murid biasa dilaksanakan ketika penerimaan raport. Laporan tersebut dilakukan komite sebagai bentuk transparansi sekaligus pembuktian bahwa sumbangan sukarela oleh wali murid benar-benar direalisasikan. Laporan komite sekolah terkait program/kegiatan di SDN Blimbing 4 Malang dilakukan saat penerimaan raport namun, pada saat itu pula sebagai ajang evaluasi program yang telah terlaksana dan evaluasi kinerja komite selama setahun. Hal ini sesuai dengan pendapat Mulyasa (2013:189-190) bahwa peran komite "melakukan evaluasi dan pengawasan terhadap perencanaan kebijakan, program, dan output pendidikan".

Peran kepala sekolah sebagai pemimpin sekolah merupakan kunci keberhasilan sebuah lembaga pendidikan dalam mencapai tujuan pendidikan. kepala sekolah didefinisikan Asmani (2012:18): kepala 
sekolah adalah jabatan fungsional yang diberikan oleh lembaga yang menaungi sekolah, bisa yayasan, Kementerian Pendidikan Nasional, Kementerian Agama, atau yang lainnya, baik melalui mekanisme pemilihan, penunjukan, maupun yang lainnya kepada seseorang. Penetapan kepala sekolah oleh lembaga-lembaga ini tentu dengan pertimbangan matang, khususnya berkaitan dengan kualifikasi yang dibutuhkan agar mampu menjalankan tugas dan tanggung jawab besarnya dalam memimpin sekolah.

Berdasarkan temuan penelitian mengenai strategi kepala SDN Blimbing 4 Malang yakni Kepala sekolah berkoordinasi dengan komite sekolah. Hal ini merupakan strategi kepala sekolah yang efektif sehingga komite selalu dilibatkan dalam program atau kegiatan sebagai upaya meningkatkan mutu sekolah maka dari itu dianggap sangat penting. Hal ini sesuai dengan konsep seperti yang dijelaskan Mulyasa (2014:51) yang mengatakan bahwa: kepala sekolah yang baik merupakan salah satu kunci dalam menciptakan hubungan yang baik antara sekolah dan masyarakat secara efektif. Kepala sekolah diharuskan dapat memberikan perhatian yang lebih terhadap permasalahan-permasalahan yang terjadi pada peserta didiknya dan mampu memahami apa yang diharapkan dari orang tua. Disamping itu juga diharapkan mampu memberikan perhatian lebih kepada komite sekolah yang dapat diwujudkan dengan mengundangnya pada setiap kegiatan yang dilakukan sekolah dan menjenguk anggota atau pengurusnya yang sakit.

Cara kepala sekolah berkoordinasi dengan komite dalam program atau kegiatan sekolah upaya mewujudkan tujuan pendidikan. Selain itu, hubungan antara sekolah dan masyarakat dimaksudkan untuk meningkatkan keterlibatan, kepedulian, serta rasa kepemilikan terhadap sekolah. Oleh karena itu, kepala sekolah memerlukan cara lain yakni melakukan pendekatan-pendekatan kepada masyarakat atau yang bersangkutan. Berdasarkan temuan penelitian bahwa strategi kepala SDN Blimbing 4 Malang juga dengan melakukan pendekatan-pendekatan. Hal ini sesuai dengan konsep yang disebutkan Wahjosumidjo (dalam Kompri, 2014:306), beberapa pendekatan yang dapat digunakan oleh kepala sekolah dan tenaga kependidikan untuk menggalang partisipasi masyarakat, yaitu: 1. melibatkan masyarakat dalam berbagai program dan kegiatan di sekolah yang bersifat sosial kemasyarakatan, seperti bakti sosial, perpisahan, peringatan hari besar nasional, keagamaan, dan pentas seni. Pelibatan masyarakat disesuaikan dengan hobi, kemampuan, dan pekerjaan mereka dengan program dan kegiatan yang akan dilakukan sekolah, 2.mengidentifikasi tokoh masyarakat, yaitu orang-orang yang mampu mempengaruhi masyarakat pada umumnya. Tokoh tersebut yang pertama kali harus dihubungi, diajak kompromi, konsultasi, dan diminta bantuan untuk menarik masyarakat berpartisipasi dalam program dan kegiatan sekolah. tokoh-tokoh tersebut mungkin berasal dari orang tua peserta didik, figur masyarakat (kiai), olahragawan, seniman, informal leaders, psikolog, dokter, dan pengusaha.

Pelibatan masyarakat utamanya komite dalam program sekolah merupakan salah satu strategi kepala sekolah untuk mendukung penyelenggaraan pendidikan sebab, hal tersebut menjadi tugas bersama yakni pemerintah, sekolah, dan masyarakat. Ketiga komponen itu diharapkan mampu bersinergi meningkatkan mutu pendidikan yang meliputi perencanaan, pelaksanaa, dan evaluasi. Masyarakat atau komite dalam hal ini juga berperan sebagai sumber, pelaksana, dan pengguna hasil pendidikan itu sendiri. Namun, seorang kepala sekolah sebagai guru yang diberi tugas tambahan tersebut harus paham tentang tugas dan fungsinya dalam sebuah sekolah, serta mampu mempraktikkannya dalam kegiatan sehari-hari di kehidupan sekolah. Hal itu dilakukan karena sebagai pemimpin, modal awal yang wajib dimiliki ialah harus menjadi panutan yang baik bagi warga sekolah dan masyarakat.

Strategi kepala SDN Blimbing 4 Malang lainnya ialah kepala sekolah memposisikan dirinya sebagai contoh atau sosok teladan. Hal ini seperti yang dijelaskan dalam jurnal Triwiyanto (2018:133), disebutkan pentingnya kepala sekolah dalam menggerakkan masyarakat yakni: karena pentingnya faktor kepala sekolah ini, maka diperlukan figur dengan kapasitas memadai, kompetensi untuk mengelola hubungan sekolah dan masyarakat dalam rangka pencarian dukungan gagasan, sumber belajar, dan pembiayaan sekolah. Selain itu diperlukan kemampuan kepala sekolah untuk mengelola perubahan dan pengembangan sekolah menuju organisasi pembelajar yang efektif. Kepala sekolah dituntut mampu menjalan fungsi hubungan dengan masyarakat dengan baik. 
Berdasarkan uraian di atas, kepala sekolah disamping menggerakkan warga sekolah serta masyarakat juga harus memberikan contoh dengan menjadi panutan yang baik dengan menjalankan peran dan fungsinya yang telah diatur. Dengan ini, kepala sekolah selain dapat menggerakkan seluruh komponen berarti juga memperoleh kepercayaan masyarakat terutama orang tua atau wali murid. Maka, apapun bentuk program atau kegiatan yang direncanakan akan berjalan baik dan lancar karena dukungan tersebut.

Rencana kegiatan yang disusun tidak selalu berjalan baik sebab dalam pelaksanaannya ditemukan kendala-kendala. Hal ini dapat dikertahui dari temuan penelitian di SDN Blimbing 4 Malang yaitu pada saat ada pertemuan tidak semua pengurus komite dapat hadir dikarenakan sibuk dengan pekerjaan masing-masing. Berdasarkan temuan penelitan tersebut juga ditemukan hasil penelitian yang hampir sama oleh temuan penelitian Firdiana (2012:73) bahwa ada beberapa kendala partisipasi komite sekolah dalam pelaksanaan program di SMP Negeri 1 Bakung yaitu: mayoritas mata pencaharian wali murid sebagai petani, sehingga komite sekolah kesulitan dalam mencari waktu untuk musyawarah. Perwakilan masyarakat yang tergabung dalam komite sekolah juga memiliki pekerjaan yang tidak bisa sewaktuwaktu ditinggalkan apabila di sekolah ada pertemuan yang sifatnya insidental/mendadak. Hal tersebut tentu akan menghambat kinerja para komite sekolah dalam menjalankan tugasnya. Kendala yang ditemui komite sekolah lainnya adalah adanya asumsi masyarakat tentang biaya pendidikan gratis karena sudah ada dana BOS.

Berdasarkan hal itu dapat diketahui bahwa kendala dapat berasal dari komite maupun orang tua atau wali murid. Keduanya memiliki permasalahan yang sama yakni sulit menentukan waktu untuk melakukan pertemuan atau rapat dengan anggota yang lengkap dikarenakan masing-masing perwakilan dari komite dan orang tua memiliki kesibukan seperti pekerjaan. Namun, permasalahan lainnya terjadi saat pertemuan orang tua di SDN Blimbing 4 Malang yakni wali murid yang tidak setuju dengan program atau kegiatan sekolah. Wali murid yang tidak setuju mayoritas menolak untuk menyumbang dana atau bahkan tidak ikut berpartisipasi seperti kerja bakti. Terkait permasalahan yang bisa terjadi dalam pelibatan masyarakat tersebut dijelaskan oleh Mulyasa (2012:145), bahwa: dalam pelaksanaannya, sering terjadi tokoh masyarakat yang dilibatkan dalam kegiatan sekolah memiliki gagasan yang berbeda dengan program pengembangan sekolah. perbedaan pendapat memang seringkali menjadi permasalahan ketika merencakan sebuah program kerja sekolah, beberapa diantaranya misalnya seperti belum paham arah dan tujuan program itu sendiri sehingga tidak jarang banyak yang tidak setuju. Maka penting sekali agar sekolah dapat menginformasikan dengan tepat agar kesalahpahaman tidak terjadi sehingga rencana kerja sekolah dapat berjalan dengan baik.

Dalam pertemuan tidak jarang permasalahan yang timbul dari keduan belah pihak yakni komite dan orang tua terjadi misalnya orang tua atau wali murid tidak setuju dengan rencana program sekolah. Namun, permasalahan yang terjadi di SDN Blimbing ini yakni beberapa orang tua yang tidak setuju sehingga permasalahan ini juga menjadi tugas komite untuk meluruskan kendala-kendala tersebut agar ditemukan alternatif pemecahan masalahnya.

Kendala-kendala yang timbul dalam upaya peningkatan mutu pendidikan perlu ditindaklanjuti agar rencana program sekolah dapat berjalan dengan baik. Berdasarkan hasil temuan di SDN Blimbing 4 Malang, solusi pemecahan masalahnya yakni komite yang berhalangan hadir dapat digantikan oleh pengurus komite lainnya namun tetap berkoordinasi dengan pengurus yang tidak hadir. Pemecahan masalah terkait dengan komite tersebut disebutkan dalam jurnal Triwiyanto (2018:134), bahwa saran untuk mengurangi hambatan komite sekolah untuk memiliki program kerja yaitu:

(1) perlunya petunjuk teknis pembuatan program kerja untuk komite sekolah; (2) perlunya program yang utuh dapat menyentuh sampai pada kebutuhan sekolah,dan masyarakat, bukan sekedar pada level provinsi saja; (3) perlunya anjuran dari kementerian pendidikan, dinas pendidikan provinsi berupa surat untuk melaksanakan program kerja dengan peran serta masyarakat di daerah; (4) perlunya monitoring dan evaluasi sebagai kontrol kegiatan program komite sekolah; (5) pengawas perlu mendampingi komite sekolah untuk membuat program kerja; (6) perlunya dilakukan pelatihan bagi komite sekolah di masingmasing daerah untuk meningkatkan program kerja komite sekolah; (7) perlunya dibangun komunikasi 
yang harmonis antara pengurus komite dan pihak sekolah; dan (8) perlunya rembug gugus (mengundang kepala sekolah dan komite) dengan tema peran serta masyarakat.

Bersarkan temuan penelitian di atas, hal yang dilakukan komite ialah berkoordinasi dan membangun komunikasi. Kedua cara tersebut merupakan kunci komite sekolah mengatasi permasalahan. Komite dan orang tua harus memiliki satu suara atau mencapai mufakat untuk mencegah kesalahan informasi. Sehingga, koordinasi dan komunikasi merupakan cara paling solutif untuk menjagan hubungan antara sekolah dan masyarakat terlebih untuk mencapai tujuan pendidikan. Disamping itu, SDN Blimbing 4 Malang memiliki solusi lainnya untuk mengatasi wali murid yang tidak setuju adalah dengan melakukan pendekatan secara personal terhadap pihak-pihak yang bertentangan tersebut. Hal ini sesuai dengan konsep yang dijelaskan Slameto dan Kriswandani (dalam Benty \& Gunawan, 2015:81), hal-hal yang bisa diusahakan antara lain: 1. melakukan persuasi kepada masyarakat, bahwa dengan keikutsertaan masyarakat dalam kebijakan yang dilaksanakan, justru akan menguntungkan masyarakat sendiri, 2. Menghimbau masyarakat untuk turut berpartisipasi melalui serangkaian kegiatan, 3. Menggunakan tokoh-tokoh masyarakat yang mempunyai khalayak banyak untuk ikut serta dalam kebijakan agar masyarakat kebanyakan yang menjadi pengikutnya juga sekaligus ikut serta dalam kebijakan yang diimplementasikan, 4. Mengaitkan keikutsertaan masyarakat dalam implementasi kebijakan dengan kepentingan mereka, masyarakat memang perlu diyakinkan bahwa ada banyak kepentingan mereka yang terlayani dengan baik jika mereka berpartisipasi dalam kebijakan.

Berdasarkan temuan penelitian di atas, sesuai dengan konsep yang disampaikan Slameto dan Kriswandai dapat disimpulkan bahwa beberapa cara yang dilakukan sekolah atau komite sekola yaitu dengan melakukan pendekatan dengan memaksimalkan keberadaan tokoh masyarakat agar masyarakat atau orang tua dapat berpartisipasi dalam kegiatan sekolah.

Dari pembahasan di atas yang diuraikan berdasarkan pada masing-masing fokus peneltian, dapat disimpulkan bahwa hal tersebut ialah upaya peningkatan mutu pendidikan khususnya di sekolah. Mutu pendidikan sebagaimana pendapat Susanto (2016:44), mengenai mutu pendidikan bahwa: pengertian mutu dalam konteks pendidikan mengacu pada proses pendidikan dan hasil pendidikan. Proses pendidikan yang bermutu melibatkan berbagai input seperti bahan ajar, metode pembelajaran, sarana sekolah, dukungan administrasi, dan sarana prasarana serta sumber daya lainnya untuk penciptaan suasana sekolah yang kondusif. Mutu dalam pendidikan untuk menjamin kualitas input, proses, produk/ output, dan outcome sekolah sehingga dapat meningkatkan akuntabilitas sekolah

Berdasarkan hal itu, dapat dinyatakan bahwa semua upaya yang dilakukan hanya bertujuan untuk memberikan pelayanan yang baik bagi pengguna yakni peserta didik dan masyarakat. Upaya yang dilakukan ialah dengan bekerjasama dengan komite guna mendukung sekolah dalam hal pengadaan sarana dan prasarana dan penyelenggaraan program atau kegiatan sekolah.

\section{KESIMPULAN}

\section{Kesimpulan}

Keberadaan komite di SDN Blimbing 4 Malang membantu dalam pengembangan sekolah guna meningkatkan mutu pendidikan, sehingga beberapa kekuatan yang di miliki komite diantaranya: (a) keaktifan komite dalam program sekolah, (b) kesigapan komite dalam menindaklanjuti masalah, (c) pembagian kerja yang jelas pengurus komite sekolah yakni yang beranggotakan ketua komite, wakil ketua, sekretaris, bendahara, dan paguyuban kelas, dan (d) koordinasi yang terjalin baik (warga sekolah, orang tua, dan antar pengurus komite)

Pentingnya pelibatan komite dalam program atau kegiatan sekolah dapat diketahui dari bentukbentuk pelibatan komite sekolah dalam program atau kegiatan sekolah, bentuk-bentuknya ialah sebagai berikut: (a) mengadakan pertemuan yang dihadiri oleh kepala sekolah, pengurus komite, paguyuban kelas, para guru, dan wali murid, (b) menggalang dana, (c) mengontrol keuangan, (d) melibatkan dan mengarahkan orang tua dalam program sekolah, (e) melaporkan hasil kegiatan kepada orang tua. 
Cara atau strategi kepala sekolah dalam melibatkan komite sekolah dalam upaya peningkatan mutu pendidikan juga sangat penting karena sebagai pemimpin sekolah yang bertanggungjawab penuh dalam segala pelaksanaan kegiatan sekolah. maka kepala sekolah perlu memiliki cara atau strategi agar komite bersama-sama dengan sekolah membangun sekolah yang bermutu. Hal-hal yang dapat dilakukan diantaranya: (a) berkoordinasi dengan komite, (b) melakukan pendekatan-pendekatan, (c) kepala sekolah menjadi suri tauladan.

Dalam pelaksanaannya tidak semua rencana dapat berjalan dengan baik sehingga tidak jarang kendala-kendala muncul sehingga komite diharuskan untuk menyelesaikan permalahan tersebut agar rencana lain yang telah disusun dapat terlaksana atau tidak mengganggu kegiatan lainnya. Permasalahan yang dihadapai komite dalam pelaksanaan program atau kegiatan dalam upaya meningkatkan mutu yaitu: (a) pengurus komite jarang lengkap (anggota) saat pertemuan, dan (b) wali murid keberatan pada program khususnya saat sumbangan sukarela.

Untuk mengatasi permasalahan-permasalahan yang muncul tersebut komite bersama sekolah perlu menindaklanjutinya sebagaimana hasil temuan yaitu: (a) pengurus yang berhalangan hadir digantikan dengan pengurus lainnya, dan (b) melakukan pendekatan secara personal.

\section{DAFTAR RUJUKAN}

Asmani, Jamal Ma’ruf. 2012. Tips Aplikasi Manajemen Sekolah. Jogjakarta: DIVA Press.

Benty, Djum. Djum .Noer. \& Gunawan, Imam. 2015. Manajemen Hubungan Sekolah dan Masyarakat. Malang: UM Press.

Dwiningrum, Siti Irene. A. 2011. Desentralisasi dan Partisipasi Masyarakat dalam Pendidikan: Suatu Kajian Teoretis dan Empirik. Yogyakarta: Pustaka Belajar.

Fattah, Nanang. 2013. Sistem penjaminan mutu pendidikan. Bandung: PT Remaja Rosdakarya.

Firdiana, Windy. 2012. Partisipasi komite sekolah dalam pelaksanaan pelaksanaan program sekolah di SMP Negeri 1 Bakung Kabupaten Blitar. Skripsi tidak diterbitkan, Malang: Fakultas Ilmu Pendidikan Universitas Negeri Malang.

Kompri. 2014. Manajemen Pendidikan 2. Bandung: Alfabeta.

Mulyasa. Enco. 2012. Manajemen dan Kepemimpinan Kepala Sekolah. Jakarta: PT Bumi Aksara.

Mulyasa, Enco. 2014. Manajemen Berbasis Sekolah. Bandung: PT Remaja Rosdakarya.

Peraturan Menteri Pendidikan dan Kebudayaan Nomor 75 Tahun 2016 tentang Komite Sekolah. Staff UGM (online), (https://luk.staff.ugm.ac.id/atur/bsnp/Permendikbud75-2016KomiteSekolah.pdf), diakses 6 Januari 2018.

Sagala, Syaiful. 2011. Manajemen strategik dalam peningkatan mutu pendidikan.

Bandung: Alfabeta Bandung.

Susanto, Pendi. 2016. Produktifitas Sekolah: Teori untuk Praktik di tingkat Satuan Pendidikan. Bandung: Alfabeta.

Triwiyanto, Teguh. 2018. Hambatan Implementasi Program Kerja Komite Sekolah untuk meningkatkan Peran Serta Masyarakat. Jurnal Manajemen dan Supervisi Pendidikan, 2 (2), 131- 134. Dari http:// journal2.um.ac.id/index.php/jmsp/article/view/2671/1745.

Undang-Undang Nomor 20 Tahun 2003 Tentang Sistem Pendidikan Nasional. Ristekdikti (online), (http://kelembagaan.ristekdikti.go.id/wp-content/uploads/2016/08/UU_no_20_th_2003.pdf), diakses 2 Januari 2018. 